\title{
DO TURLOUGHS OCCUR IN SLOVENIA?
}

\author{
ALI SO V SLOVENIJI OBČASNA KRAŠKA JEZERA TIPA \\ »TURLOUGH«?
}

\author{
Micheline SHEEHY SKEFFINGTON ${ }^{1 *}$, Nick. E. SCOTT ${ }^{2}$
}

\begin{abstract}
UDC 551.432.5 (497.4)

Micheline Shehy Skeffington \& Nick. E. Scott: Do turloughs occur in Slovenia?

Turloughs are karst basins that fill seasonally with mostly groundwater and drain, usually in summer, to reveal a sedge or grassland community. They are often described as being virtually unique to Ireland. The much larger seasonal poljes of the Slovenian karst are considered different to turloughs. However, a series of small temporary karst lakes in the Slovenian Pivka valley seem remarkably similar to Irish turloughs. Like turloughs, they fill and empty largely through estavelles connecting to underground water systems, which rise and fall with high seasonal rainfall. The Slovenian sites, however, support less wetland communities than Irish turloughs, probably due to drier summer conditions. The plant communities of both systems occur in zones around the basin, related to flood duration. Relevés taken at five Slovenian sites revealed that Petelinjsko jezero, which floods longest each year, is the most similar to turloughs, with, in the lower basin, Eleocharis palustris, Potentilla reptans and the unusual form of Ranuculus repens commonly found in Irish turloughs. The difference in climate and terrain means that the Slovenian sites are managed for hay or silage, while the Irish turloughs are under pasture. However, for both, regular flooding precludes much agricultural improvement, so that they are now refuges for flora and fauna. A revised definition for turloughs is proposed and a case made for these Slovenian wetland systems to be recognised as turloughs and for the EU Habitats Directive to be amended to include poljes and other similar temporary karst wetland systems as well as turloughs.
\end{abstract}

Keywords: turloughs, karst, polje, temporary wetlands, Ireland, Slovenia, European Habitats Directive.

\section{Izvleček \\ UDK 551.432.5 (497.4) \\ Micheline Shehy Skeffington \& Nick. E. Scott: Ali so v Sloveniji občasna kraška jezera tipa "turlough«?}

Turlough je kraška globel, ki jo začasno zalije predvsem kraška talna voda. Ta, $v$ glavnem poleti, odteče in omogoči rast združb trav oziroma močvirnih trav. Pogosto je opisan kot izključno irski pojav. Veliko večje občasno poplavljene depresije slovenskega krasa - kraška polja, se štejejo kot različna od turlougha. Vendar pa kaže, da je vrsta majhnih občasnih jezer v dolini Pivke močno podobna irskim turloughom. Tako kot turloughi se skozi estavele polnijo in praznijo in so preko njih povezane s podzemeljsko vodno mrežo, ki se dviga ali pada glede na dež. Vendar pa je za slovenske primere značilno manj mokrotnih združb, kot za irske turloughe, čemur so najbrž vzrok sušnejša poletja. $\mathrm{V}$ obeh primerih so rastlinske združbe razporejene $\mathrm{v}$ pasovih okoli depresij, glede na trajanje poplav. Vzorci s petih nahajališč v Sloveniji kažejo, da je Petelinjsko jezero, ki je najdlje poplavljeno, najbolj podobno turloughu. $\mathrm{V}$ najnižjem delu rastejo Eleocharis palustris, Potentilla reptans in neobičajna oblika Ranunculus repens, običajna za irske turloughe. Zaradi razlik v podnebju in površju, se slovenski primeri izkoriščajo predvsem za seno ali silažo, irski pa kot pašniki. $V$ obeh pa predstavljajo poplave oviro za poljedeljsko izrabo in so zato danes zatočišča za floro in favno. Predlagana je nova definicija turlougha, s tem pa bi bila tudi ta slovenska mokrišča priznana za turloughe in tako bi evropska direktiva o habitatih lahko vključevala tudi kraška polja in druga občasna kraška mokrišča, tako kot turloughe.

Ključne besede: kraško polje, kras, občasno mokrišče, Irska, Slovenija, Evropska direktiva o habitatih.

\footnotetext{
${ }^{1}$ Department of Botany, National University of Ireland, Galway, Galway, Ireland micheline.sheehy@nuigalway.ie

${ }^{2}$ Seagal, Ballinacourty, Clarinbridge, Co Galway, Ireland.

* Corresponding author. Phone $+353-91-492682$; fax $+353-91-494535$
}

Received/Prejeto: 26.9.2007 


\section{INTRODUCTION}

The term 'karst' is used to describe limestone landscapes that have many features resulting from the high permeability and solubility of the rock. The rock may be several hundred million years old, as in the Lower Carboniferous limestones of the Irish karst, or younger as in the Upper Cretaceous limestones of Slovenia. Such regions are usually famous for their caves and underground rivers, but smaller features such as dolines, which result from collapsed or eroded cave systems, are also common. Temporary lakes in such hollows can also sometimes be a feature. These occur in both Ireland and Slovenia. Both countries have extensive areas of karst and high levels of rainfall which results in seasonal flooding. The Slovenian lakes are known as poljes while the Irish lakes are called turloughs and the two are usually thought to be very different. In the English literature Slovenian poljes are said to be much larger than turloughs; to flood for much longer periods, to greater depths; and unlike turloughs, to have rivers running through and sinking within them (Sweeting 1972; Coxon 1986; Ford and Williams 1989). The terms turlough and polje have thus become used to describe different types of karst temporary lake. This distinction has allowed the often-made claim that turloughs are virtually unique to Ireland (Sheehy Skeffington et al. 2006). Turloughs are described and listed as priority habitats in the European Union Habitats Directive (EEC 1992) and reference is only made to Ireland in the Habitats Directive manual (Anon. 2003).

During an initial brief visit by one author (NES) in 2004 to Slovenian karst wetland sites and then in 2006 by MSS with local scientists, it became clear that, whereas the large poljes such as Cerkniško polje, Radensko polje and Planinsko polje, are distinctly different to turloughs, the flooded part being several $\mathrm{km}$ long and wide, with deep soils and small river systems rising and sinking within the polje; there are also a number of much smaller temporary lakes that appear to flood and drain in much the same way as the Irish turloughs. The smaller sites visited were all in the Pivka valley. This is drained by the Pivka River that runs into the cave system of Postojnska Jama beside the town of Postojna in south-western Slovenia (Fig. 1).

There has been discussion in Slovenian karst literature concerning the classification of their karst depressions which can be dry, flood only occasionally or flood seasonally (Gams et al. 1973, 2004; Ravbar \& Šebela 2004; Šebela 2005). Gams (2004) made a distinction inter alia between the larger poljes with a wide, elongated basin, steep slopes, sinking river and karst outflow and the smaller more circular basins with temporary lakes, which may fill seasonally with water through estavelles.
These basins are bigger than the dry dolines (Ravbar and Šebela 2004). There is also some debate in Slovenia concerning the Pivka valley temporary lakes, where it has been suggested that they are not like the large poljes which are now believed to be primarily caused by geological faults, but are in fact a completely different type of karst depression (Habič 1968, 1975 in Šebela 2005). In discussing the varied terminology, Ravbar and Šebela (2004) refer to recent differences of opinion concerning the formation of these basins and make a case for further study of the Pivka valley temporary lakes. They also suggest that these lakes require a new karst term of their own.

This paper attempts to describe the Pivka valley temporary lakes from an Irish perspective. The hydrogeological features of turloughs and the Slovenian temporary lakes will be reviewed briefly to compare the two systems. Then, based on observations made in July 2006 by both authors, the Pivka sites and their vegetation are described, and features highlighted that are different from, or similar to turloughs. In this way, it is attempted to assess whether, within the range of temporarily flooded basins in the Pivka valley, there are any that resemble turloughs and whether it is possible to suggest that 'turlough' could be the 'new karst term' that Ravbar and Šebela (2004) were looking for.

\section{SUMMARY OF IRISH TURLOUGH FEATURES}

A full geomorphological description of turloughs in Ireland is in Sheehy Skeffington et al. (2006) and Sheehy Skeffington and Gormally (2007). The only turlough so far recognised outside of Ireland is in south-west Wales, to the east of Ireland, occurring on Carboniferous limestone and receiving similar, or slightly lower, rainfall levels. Its occurrence is, however, due to local faulting (Campbell et al. 1994) which does not appear to be the case for any Irish turloughs. Sheehy Skeffington et al. (2006) suggested that the apparent near-confinement of turloughs to Ireland may be due to the occurrence only there of the combination of high levels of rainfall with a low-lying and exposed karst landscape.

In Ireland only three turloughs occur in an upland region: the Burren where the surrounding hills reach $300-400 \mathrm{~m}$. The basins are entirely enclosed and their floors are roughly $200 \mathrm{~m}$ above sea-level. They appear to fill due to the impervious nature of the basin floor caused by underlying more impervious cherty limestones, and marls and glacial deposits (Drew 1990). The biggest, Carron Turlough, also has a river running through part of it and because of these similarities it has been called a polje (Sweeting 1953, 1972). 


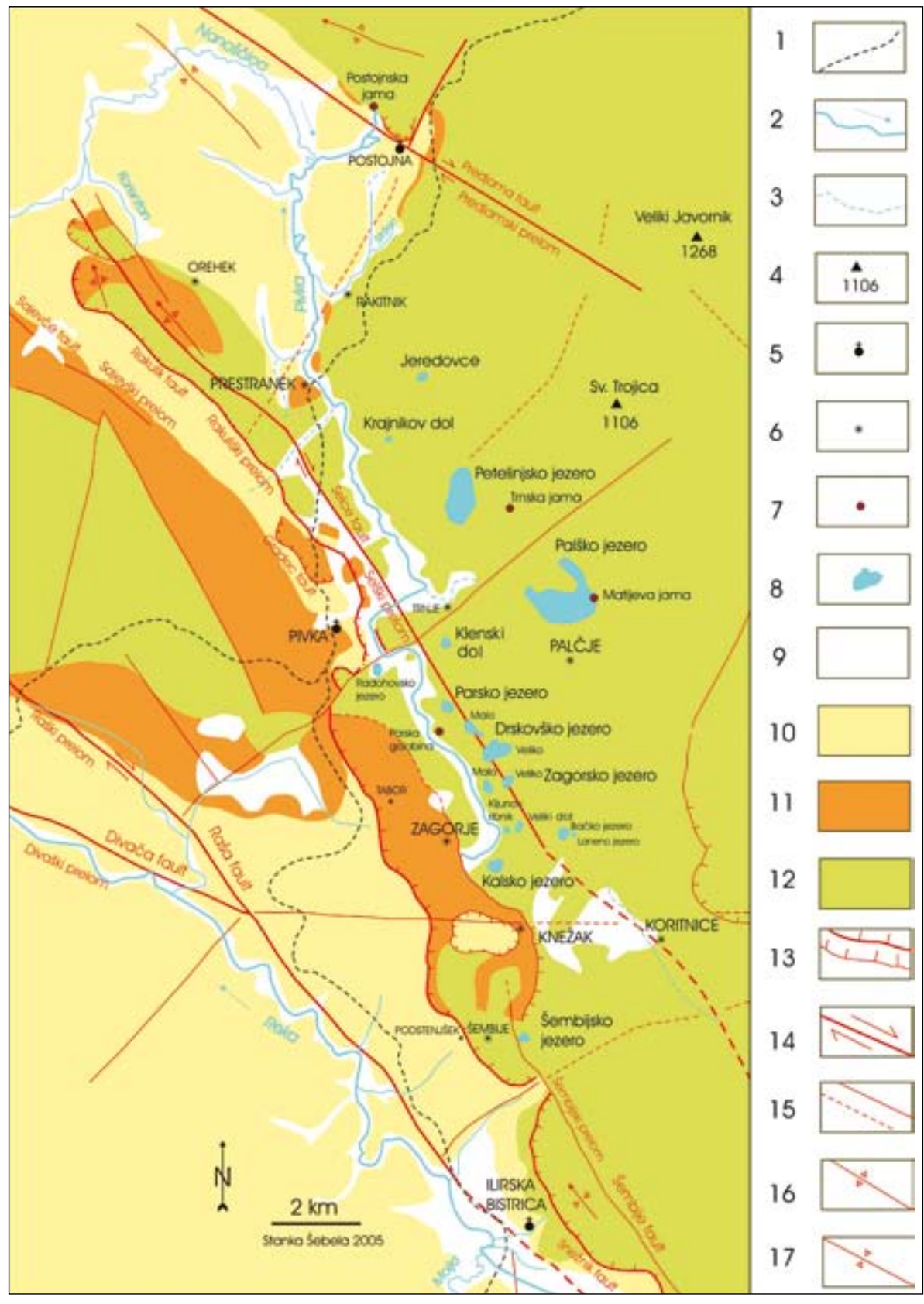

Fig. 1: Map of the Pivka River, showing location of the intermittent lakes and the local geology (from Šebela, 2005, with permission from Acta Carsologica ). Key: 1: railroad, 2: river with flow direction, 3: occasional stream, 4: hill with altitude a.s.l., 5: town, 6: smaller town, 7: karst cave, 8: intermittent lake, 9: alluvium (Quaternary), 10: flysch (Eocene), 11: limestone (Palaeogene), 12: mostly limestone (Cretaceous), 13: thrust fault; stronger and weaker, 14: dextral movement along horizontal fault, 15: fault, established and covered, 16: anticline, 17: syncline.

Most turloughs dry out completely for a sufficient length of time during the growing season for their floors to be fully vegetated. The plant communities can be wet grassland or sedge-dominated swards, depending on the substrate moisture and its nutrient status (O'Connell et al. 1984; Goodwillie 2003). Most of the vegetation in turlough basins is assignable to either the phytosociological alliance Agropyro-Rumicion crispi (wet grassland, in the Class Plantaginetea majoris) or the Caricion canescenti-nigrae (sedgedominated and related to the Caricion davallianae in the Scheuchzerio-Caricetea fuscae) (O’Connell et al. 1984). There are no shrubs in turlough basins. It seems likely that this is natural, but as all turloughs are now grazed, this is not certain. There is some evidence that exceptionally high flooding (such as in the winter 1989/1990) kills shrubs like Juniperus communis, and keeps species such as Fraxinus excelsior, Crataegus monogyna and Rhamnus cathartica in check round the edge of some lessgrazed turloughs (Goodwillie 2003).

Virtually all turloughs are grazed by domestic stock. The mild winters traditionally allowed animals to be kept out on drier land in the winter and they would then be let out onto the turlough as it dries out. The pattern of land ownership round a turlough basin - usually one of fields radiating across or out from the central basin - reflects its use for summer grazing and as a water source for animals (Sheehy Skeffington \& Gormally 2007).

Turloughs are of high conservation importance not so much for their plant communities - though some are becoming rare across Europe- but for the invertebrate assemblages, both aquatic and wetland, and for the winter bird visitors that they support (Sheehy Skeffington et al. 2006). The variety of grazing systems both within and between turloughs helps to maintain the diversity of the systems and it is important that the farming commu- 
nity be encouraged to continue such practices in these somewhat marginal lands (Ní Bhriain et al. 2003; Sheehy Skeffington \& Gormally 2007). As priority habitats in the EU Habitats Directive, most turloughs over 10 ha have Special Area of Conservation (SAC) protection status; eight of these also have Special Protection Area (SPA) status under the Birds Directive (Sheehy Skeffington et al. 2006); two are also in a National Park and three in a National Nature Reserve.

\section{SUMMARY OF SLOVENIAN TEMPORARY LAKE FEATURES}

The temporary lakes of Slovenia all appear to occur in linear patterns within the long valley depressions formed by faulting and thrusting of the rocks which run SE-NW through the Slovenian Karst (Gams 2004). Most occur around $300-500 \mathrm{~m}$ above sea-level and are flooded in autumn and spring when the increased outflow of the water-table is impeded by less permeable rocks (Kranjc 2006; Mihevc 2006). The rainfall in the Ljubljanica river system, where most of the poljes occur, varies from 1,300 to $3,000 \mathrm{~mm}$ over $100-150$ days (Mihevc 2006). Winter precipitation is usually as snow and is retained on the land. The basins do not always drain fully during mid-winter, as the water freezes - indeed ice was traditionally harvested from several temporary lakes (Erajvec \& Peršič 2005). The catchment for the temporary lakes consists of multiple underground sources of drainage from the adjacent limestone mountain ranges that peak to between $700 \mathrm{~m}$ and $1300 \mathrm{~m}$. The basins are comparatively flat and the transition to higher ground around the edge can be abrupt, due to the lateral corrosion of the rock by the standing water (Mihevc 2006). Mihevc (pers. comm.) suggests that the Pivka depressions may have different origins to larger poljes, some may be solution dolines, others remnants of a former levelled surface that was lowered by tectonic, lithological or structural action. However, in all cases, those that flood seem to because the water table comes into contact with the bases of these depressions and therefore the sediment per se does not cause the flooding, but accumulates as a result of it ( $\mathrm{Mi}-$ hevc, pers. comm.).

A significant difference from Ireland is that the nonAlpine regions where most temporary lakes occur were not glaciated during the Quaternary. Thus karst features have developed over several million years without the scouring of the land surface and deposition of glacial debris that is inherent to more northern landscapes, such as Ireland.

All the temporary lakes in Slovenia have at least some or all of their floors covered with mesic or wet grassland (Lovka 2000; Mulec et al. 2005). Depending on the slope of the basin, a series of vegetation zones is evi- dent from the fringe to the damper centre. This is more obvious in the smaller basins. The sward is regularly cut in the summer, usually in June/July, mostly for hay, but there is increasing use of silage bales, which enables an earlier cut. Land use in Slovenia still resembles the mediaeval system in which the better land is divided in strips. Each farmer may own one or more strips that vary from ca 5 to $100 \mathrm{~m}$ in width and $200-300 \mathrm{~m}$ in length. The differences in cutting time, and more recently abandonment, bring heterogeneity to the vegetation composition and structure across the basin floor. No walls exist between strips and fences are rare, the occasional post demarcating ownership.

Because of the long cold winters in the Slovenian uplands, extensive areas are required for cattle fodder and so the valley bottoms and the temporary lakes, which are flat and have deeper soils have traditionally been reserved for hay or silage (A. Mihevc, pers. comm.). However, farming incomes are now so meagre that the hillside land which was once used for summer grazing has mostly been abandoned and is now scrub or young woodland. Many modern dairy herds are of a variety that are not adapted to rough pasture and are kept in barns within the villages where they are fed with hay or silage (S. Peteline, pers. comm.). Sometimes slurry or fertiliser is spread on the temporary lakes and they can be cut more than once. This retreat from the land is threatening biodiversity (Pečnik 2004). Sheep farming is currently becoming more widespread (Pečnik 2004; Mulec et al. 2005), for which hay is less necessary.

Some temporary lakes are protected in Slovenia. Planinsko polje is part of the Planinsko Polje Landscape Park and several of the Pivka temporary lakes are National Monuments (Pečnik 2004). As part of joining the EU, Slovenia has prepared a list of candidate Natura 2000 sites (Pečnik 2004). This lists the Pivka valley temporary lakes as a candidate site, along with Cerkniško, Planinsko, Radensko and Ribniško poljes. Most are listed as they support a number of Habitats Directive habitats particularly associated with poljes, and some priority habitats, such as Molinia grassland which occurs in many of the larger poljes but rarely in the smaller temporary lakes of the Pivka valley. Many sites are also listed for their fauna, notably the corncrake Crex crex which nests in the Pivka valley, but also butterflies, beetles, crustaceans and migrating birds that also appear to use at least one lake as a winter resting site (Pečnik 2004; Pipan 2005).

This paper distinguishes between the larger flooded poljes and the smaller temporary lakes of the Pivka valley, as these latter appear to more closely resemble Irish turloughs. This is not intended to be a comprehensive account of Slovenian temporary lakes, but more a resumé of the main features of each with reference to the 
Irish systems. This refers only to those sites visited by the authors, which include most of the large poljes and many of the smaller systems in the Pivka valley.

\section{THE LARGER POLJES}

Three sites were visited; the biggest polje in Slovenia, Cerkniško polje, with a basin extending over $38 \mathrm{~km}^{2}$, Planinsko polje $\left(16 \mathrm{~km}^{2}\right)$ and Radensko polje $\left(4 \mathrm{~km}^{2}\right)$

Cerkniško polje has extensive water, even in summer, and supports an aquatic plant community with Potamogeton spp, Myriophyllum and Chara spp. Extensive beds of Phragmites australis fringe the wetter areas with Schoenoplectus lacustris and Phalaris arundinacea. The basin is very flat, but plant communities still grade from those of wet meadows, with Genista tinctoria, $\mathrm{Ga}$ lium verum, Potentilla anserina and Lotus corniculatus prominent in places, into drier fields, most of which were cut for hay by mid-July.

Planina polje has less extensive permanent water, but is fed most of the time by rivers which support fish such as trout. It is flooded for up to 6 months in the year and the meadows are cut for hay or silage in June-July.

Radensko polje supports a wider range of plant communities, with a more peaty substrate in places supporting Molinia caerulea-dominated heath and meadow species, such as Calluna vulgaris, Succisa pratensis and Filipendula ulmaria. Nardus stricta also occurs and even Sphagnum moss. It is traversed by several rivers, all of which sink within the polje system.

\section{THE PIVKA VALLEY TEMPORARY LAKES}

The Pivka river runs through the valley, rising as a series of springs at the side of limestone hills near the village of Zagorje (Fig. 1). It flows only intermittently above ground until it reaches the impervious flysch near Postojna, some $15 \mathrm{~km}$ to the north (Mulec et al. 2005). Beyond Postojna it disappears a few times, flowing into Planinsko polje and eventually emerging as the Ljubljanica River that flows through Ljubljana. The Pivka valley contains a series of terraces, some with basins that temporarily hold water (Kranjc 1985 in Mulec et al. 2005). When rainfall is high and sustained, the river fills from several activated springs along the valley sides. A complex combination of water table rising and spring activation also fills some or most of the doline-type depressions in the valley system (Mulec et al. 2005). Some only fill in extreme rainfall conditions, such as following the very high rains in November 2000 (Kovačič \& Habič 2005).

The Pivka river system is flooded from a catchment that drains the surrounding mountains that feed all the temporary lakes of the region. The appearance of the river above ground in the Pivka valley and the filling of the attendant temporary lakes during increased rainfall is a result of a perched water table, which is retained by the underlying impermeable flysch rock. This and the slow outflow channels further along the river, results in the water-table rising and flooding the Pivka valley system (Kovačič \& Habič 2005). The two main lakes, Palško jezero and Petelinjsko jezero, flood every year, to average depths of almost $13 \mathrm{~m}$. Thirteen other temporary lakes are associated with the Pivka River, of which 10 flood regularly, but only to an average depth of 1-3.8 m (Kovačič \& Habič 2005). Another four, of which one, Šembijsko jezero, floods regularly (average depth $1.2 \mathrm{~m}$ ), are associated with the adjacent Reka River that drains into the Adriatic (Kovačič and Habič, 2005).

The two largest lakes in the Pivka system are similar in size to that of the larger Irish turloughs; Palško jezero reaches 102.7 ha $(23 \mathrm{~m}$ depth) and Petelinjsko jezero 73.6 ha (9 m depth) on an average full flood (Kovačič \& Habič 2005). The other temporary lakes range in size from 0.07 to 5.6 ha and are therefore similar in size to the majority of Irish turloughs. All appear to have flatter basin floors than turloughs. The flat floors are said to be partly due to the high accumulation of alluvium and partly to the lateral corrosion of the basin sides by the floodwaters (Mihevc 2005). None has a river system flowing through the basin and most appear to fill and empty through estavelles. Palško jezero and Malo Drskovško jezero also fill/empty through springs and ponor caves. One large cave at Palško jezero acts as an estavelle, but most other estavelles are situated in the basin floor and are cavities in the alluvial sediment (Knez \& Slabe 2005).

\section{Palško jezero and Petelinjsko jezero}

Palško jezero floods for about 3 months in the year (Pečnik 2004) and is situated at $560 \mathrm{~m}$ altitude. Petelinjsko jezero, at the lowest level $(550 \mathrm{~m})$, is the longest in flood, usually roughly for 6 months (Petrič \& Kogovšek 2005). Depending on rainfall, it can flood again during the summer; for example it flooded in May 2006 (J. Mulec pers. comm.). The soils are deep and stone-free in both.

Both are divided into strips (ca $25 \mathrm{~m}$ wide), managed for hay or silage, much of which (ca 70\%) had been cut by the time of visit $\left(10^{\text {th }}\right.$ July, 2006), some harvested in silage bails. Several strips were uncut and some apparently abandoned. In Palško Jezero some had patches of scrub scattered through them. Willows (Salix purpurea) and other shrubs (Viburnum opulus, Frangula alnus, Rhamnus cathartica) occurred in clumps throughout the basin, some along apparent strip boundaries, some around the swallow holes or near big rocks, where mowing would be difficult. Petelinjsko jezero is a more circular and regular basin than Palško jezero, the surrounding 
land is higher, there is no scrub invading the basin and the vegetation zonation towards the centre of the basin is more evident. The several swallow-holes (or estavelles), 2-3 $\mathrm{m}$ deep and 1-6 $\mathrm{m}$ in diameter, scattered in the lower basin, are surrounded by particularly green and lush vegetation. At both sites deposits of silt were visible on leaves of vegetation, especially adjacent to the estavelles. Algal paper was present around the estavelles of Petelinjsko Jezero.

The grass growth in the basins was lusher and greener than in nearby dry dolines, which in turn were greener than the grassy slopes. This relates to the greater depth of soil in the basins (Lovka 2000) and its ability to retain moisture for longer; important in the hot Slovenian summers. The tree-line very clearly followed the same contour around the edge of each basin. A scrub zone that occurred within this at the basin edge comprised Corylus avellana, Rhamnus cathartica, Crataegus monogyna and Prunus spinosa, resembling the scrub around Irish turloughs. A drift-line of plant debris was visible below the pine forest, at the upper edge of each basin. At least one corncrake Crex crex was heard calling at each.

\section{Veliko Zagorsko jezero and Veliko Drskovško jezero}

These are in the southern part of the valley, where the Pivka River begins as the Pivšca spring, near the village of Zagorje (Fig 1). Each is one of a pair of basins (veliko = large); all are hidden in semi-abandoned land and are almost inaccessible as all but one of the tracks which lead to each of them have been overgrown by scrub. However, their comparative value for hay or silage is still recognised and both were recently cut. The basins were almost entirely cut (in strips), with hay bales in some or cut hay lying out to dry $\left(13^{\text {th }} J u l y, 2006\right)$. In Veliko Drskovško jezero, some strips were semi-abandoned with varying degrees of invading scrub in quite extensive patches. They are entirely surrounded by forest with oak (Quercus pubescens and Q. cerris), small-leaved lime (Tilia $s p$ ) and conifers such as Pinus sylvestris and Picea abies which again follows one contour. The scrub within this consisted of Corylus avellana, Prunus spinosa, Crataegus monogyna, Cornus sanguinea, Rhamnus cathartica, Frangula alnus, some Juniperus communis and Viburnum opulus, most of which occur commonly at the edge of Irish turloughs.

In Veliko Drskovško jezero, the damp mud around some shallow $(20-40 \mathrm{~cm}$ deep) estavelles supported a wetland plant community with Juncus acutiflorus, Ranunculus repens, Carex cf elata and Scutellaria sp.
Kalsko jezero, Veliki dol and Klenski dol

Kalsko jezero is connected to the Pivka River basin by a raised terrace above the valley, near its source. Its basin is very stony and shallow-soiled in parts and was not cut, supporting only sparse vegetation. It was possibly cut in the past, but now scrub (mostly Salix purpurea) appears to be encroaching. Some strips of land on a slightly higher ridge are cultivated with oats. Judging by their name (dol= depression jezero = lake), the other two sites may not be flooded regularly, but do support deep, relatively moist soils and the vegetation appeared lusher and greener than on the steep stony sides. Veliki dol is listed as a 'regular lake' (Kovačič \& Habič 2005) and so must flood outside exceptional flood events. Klenski dol, further down the Pivka valley, must be rarely flooded, as it contained many plots of vegetables, as well as hay. Both supported similar pasture species to those of the more regularly flooded sites (e.g. Centaurea jacea, Ranunculus acris, Lotus corniculatus) as well as plants of drier meadows such as Cerastium fontanum and Daucus carota.

\section{VEGETATION OF THE PIVKA TEMPORARY LAKES}

Twenty-nine relevés were taken at five different sites on July $10^{\text {th }}$ and $13^{\text {th }}, 2006$. All grassland relevés were $2 \times 2 \mathrm{~m}$ and four $5 \times 5 \mathrm{~m}$ scrub relevés were also taken. Vascular species nomenclature follows Tutin et al. (1964-1980) and mosses, Smith (2006). Relevés were sorted using Microsoft Excel and, using PC-ORD and excluding the 4 scrub relevés, a Nonmetric Multidimensional Scaling ordination was run, as the skewness was $>2$, indicating the need for non-parametric analysis (McCune and Grace, 2002).

The first community in Table 1 is scrub (relevés 12). This was dominated by Rhamnus cathartica, Crataegus monogyna, Prunus spinosa and some Frangula alnus and can be assigned to the Rhamno-Prunetea (Mucina, 1997). The local presence of Salix purpurea (relevés 34 ), in the absence of the other shrub species, suggests a poorly developed Salicetea purpureae.

Two main grassland communities are also represented, one classifiable into the class Molinio-Arrhenatheretea, comprising species of damp pastures and the other in the Festuco-Brometea, with species from dry, even xeric, conditions. The commonest (Companion) species are the wetland species Oenanthe of lachenalii and Agrostis stolonifera, as well as Centaurea jacea, a species of grasslands and open woods (Table 1).

The most widespread community is dominated by Galium verum, Carex humilis and Lotus corniculatus, all Festuco-Brometea species (relevés 3-20). Two variants of this community are distinguishable. One is characterised 
by the Molinio-Arrhenatheretea species Inula salicina, Phleum pratense, Genista tinctoria and Achillea millefolium (relevés 3-12). The other is dominated by Molinia caerulea with Dorycnium germanicum, Filipendula vulgaris, Trifolium montanum and, more locally, Allium carinatum (relevés 13-19). Aside from Molinia (which can grow in dry heath), these last are all species of the Festuco-Brometea (Table 1).

The second main community (relevés 20-27) is more species-poor and is ascribable to the Deschampsio-Plantaginetum altissimae in the MolinioArrhenatheretea, though it lacks many species of this class. The main species characteristic of this association are Allium angulosum, Plantago altissima and Potentilla reptans. This is a rare community in Slovenia (Lovka 2000, Mulec et al. 2005) and contains some rare species such as Gladiolus illyricus and Gentiana pneumonanthe. A variant with Galium palustre, Eleocharis palustris and Ranunculus repens $\mathrm{f}$. reptabundus (relevés 22-25) was

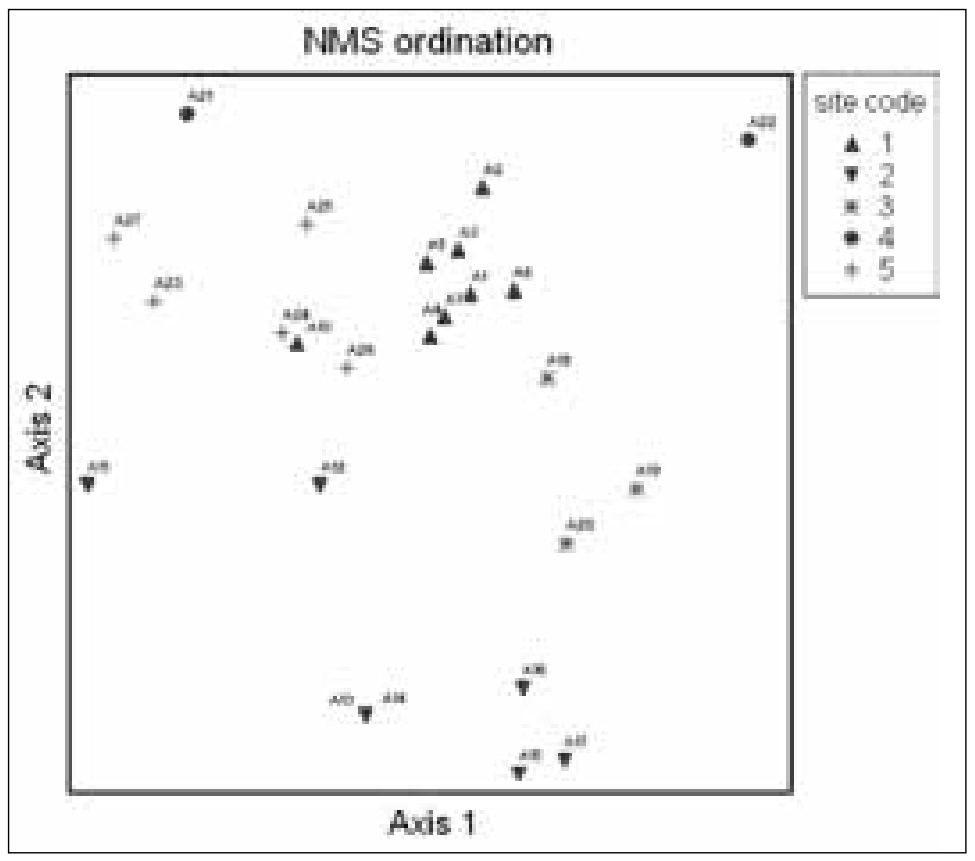

Fig. 2: NMS plot of relevés from grassland (excluding scrub relevés) in the five sites visited. 1: Palško Jezero; 2: Petelinjsko Jezero; 3: Kalsko Jezero; 4: Veliko Zagorsko Jezero; 5: Veliko Drskovško Jezero (numbered as in Table 1).

Despite the presence of elements of the FestucoBrometea, species of the Molinio-Arrhenatheretea predominate and the Deschampsio-Plantaginetum altissimae with the dominance of Molinia caerulea, is ascribable to the Molinion caeruleae, found, in eastern Europe, in intermittently wet meadows (Chytrý \& Tichý 2003).

Each site has a distinct series of plant communities. Palško jezero contains mostly a relatively dry MolinioArrhenatheretea community with Galium verum and Lotus corniculatus and the community dominated by Festuco-Brometea species is almost confined to Veliko Drskovško jezero. Petelinjsko jezero contains some dry elements at the upper edges (relevés 11-17 were taken progressively towards the centre of the basin -Table 1), but the Deschampsio-Plantaginetum altissimae with Molinia carulea predominates. Species such as Eleocharis palustris and Galium palustre were recorded only at this site and mark the wettest areas of this basin and probably of all the sites. They occur in the centre of the basin, close to the estavelles through which the basin fills and empties and where it is presumably wet for the longest time. Eight mosses were identified, most of them in Palško jezero and Petelijnsko jezero. Calliergonella cuspidata is a common moss of turloughs and Drepanocladus and Scorpidium species are also species of turloughs and fens in Ireland (Ivimey-Cook \& Proctor 1966; Moran et al. 2008b).

In the ordination of all but the 4 scrub relevés (relevés 1-4 in table 1) using NMS (Fig. 2), thirty-five percent of the variance is explained by Axis 2 and thirty percent by Axis 1 . Axis 2 seems to represent a moisture gradient and therefore duration of flood, as those relevés from the deeper part of Petelinjsko jezero (A13-A17) are at the base of the plot, whereas those taken at the edge of this basin (A11\& A12) are in the centre, closer to those of Veliko Drskovško jezero (site 5) and Palško jezero (site 1). Axis 1 distinguishes between relevés with Festuco-Brometea species (A10, A21, A23-27) from those with Molinio-Arrhenatheretea species (A1-7, A13-17) and therefore must also be related to habitat

found only in the bottom of Petelinjsko jezero. These species occur commonly in wet turlough basins in Ireland, along with the rarer Rorippa sylvestris. Connected with this are relevés from two drier sites, Kalsko jezero and Veliko Zagorsko jezero, distinguished by Poa pratensis along with Allium angulosum and Plantago altissima. wetness but perhaps due to another factor, such as retention of moisture by the substrate. The flatness of the wide basins in both Veliko Drskovško jezero and Palško jezero resulted in a similar species composition for the relevés and is reflected by the close proximity of these on the plot for each site. 
Relevé running no.

Relevé no.

site code

Festuco-Brometea species

Galium verum

Carex humilis

Lotus corniculatus

Molinio-Arrhenatheretea species

Centaurea jacea

Oenanthe cf lachenallii

Agrostis stolonifera

Inula salicina

Ranunculus acris

Phleum cf pratense

Genista tinctoria

Achillea millefolium

Vicia cracca

Valeriana officinalis

Pseudolysimachion cf longifolia

Rumex acetosa

Campanula glomerata

Carex hirta

Daucus carota

\section{Molinia caerulea}

Molinia caerulea

Festuco-Brometea species

Dorycnium germanicum

Filipendula vulgaris

Festuca ovina

Trifolium montanum

Allium carinatum

Pimpinella saxifraga

Polygala cf vulgare

Briza media

Koeleria pyramidata

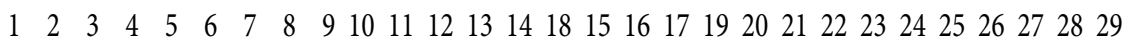

$\begin{array}{lllllllllllllllllllllllllllll}28 & 29 & 9 & 8 & 6 & 5 & 7 & 1 & 2 & 3 & 4 & 10 & 21 & 23 & 27 & 24 & 26 & 25 & 11 & 12 & 13 & 14 & 15 & 16 & 17 & 20 & 19 & 18 & 22\end{array}$

$\begin{array}{lllllllllllllllllllllllllllll}5 & 5 & 1 & 1 & 1 & 1 & 1 & 1 & 1 & 1 & 1 & 1 & 4 & 5 & 5 & 5 & 5 & 5 & 2 & 2 & 2 & 2 & 2 & 2 & 2 & 3 & 3 & 3 & 4\end{array}$ $\begin{array}{lllllllllllllllllll}2 & 1 & 1 & 2 & 4 & 3 & 4 & 5 & 4 & 5 & 3 & 2 & 4 & 3 & 2 & 3 & 2 & 2 & 2\end{array}$ $1+111+22+1++111$ $\begin{array}{llllllllllll}1 & 1 & 1 & 1 & 1 & 1 & 1 & 2 & + & 1 & 1 & 1\end{array}$
5

$\begin{array}{llllllllll}4 & 5 & 5 & 3 & 2 & 1 & 5 & 1 & 2 & 2\end{array}$
Deschampsio-Plantaginetum altissimae spp.

Allium angulosum

Plantago altissima

Potentilla reptans

Deschampsia caespitosa

Gladiolus illyricus

Carex panicea

Gentiana pneumonanthe

Other turlough wetland spp

Galium palustre

Eleocharis palustris

Ranunculus repens reptabundus

Rorippa sylvestris

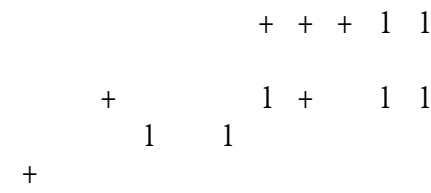

Dry meadow spp

Poa pratensis

Crepis sp.

Tragopogon cf orientalis

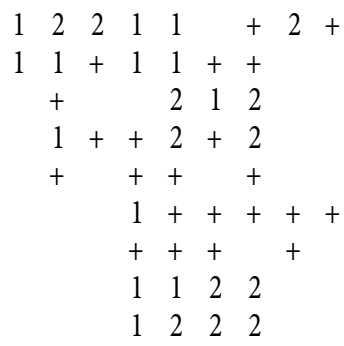

$\begin{array}{lllllll}1 & 1 & 2 & 3 & 3 & 3 & 2\end{array}$

$\begin{array}{lllllll}1 & 1 & 3 & 4 & 2 & 2 & 2\end{array}$

$++3535$

211

$1+$

$1+3$

1 
Relevé running no.

Relevé no.

site code

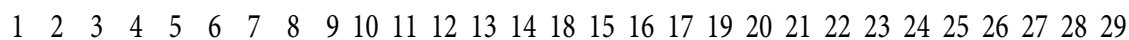

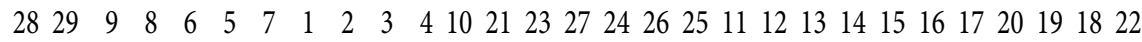

$\begin{array}{lllllllllllllllllllllllllllll}5 & 5 & 1 & 1 & 1 & 1 & 1 & 1 & 1 & 1 & 1 & 1 & 4 & 5 & 5 & 5 & 5 & 5 & 2 & 2 & 2 & 2 & 2 & 2 & 2 & 3 & 3 & 3 & 4\end{array}$

Rhamno-Prunetea species

Salix purpurea

Rubus caesius

Rhamnus catharticus

Frangula alnus

Crataegus monogyna

Euonymus europaea

Cornus sanguinea

Prunus spinosa

Juniperus communis

Rosa sp

Viburnum opulus

Solanum dulcamara

Lonicera sp

Pinus nigra

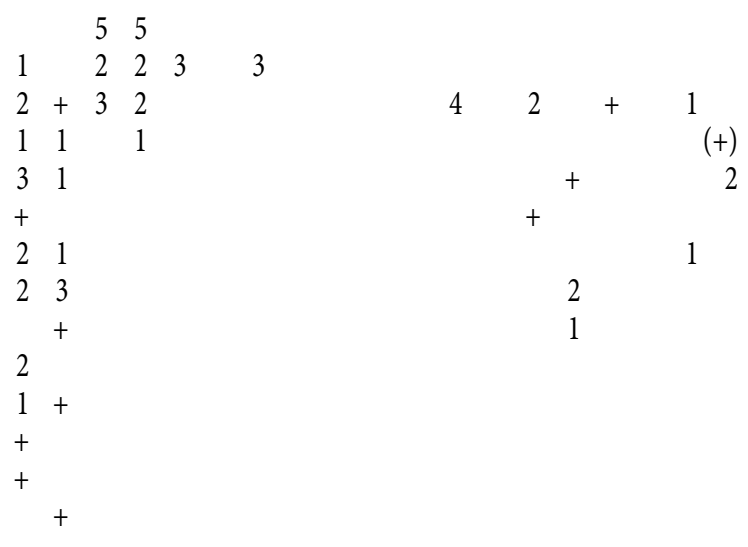

\title{
Mosses \\ Calliergonella cuspidata \\ Drepanocladus aduncus \\ D sendtneri
}

Companion species

Convolvulus arvensis

Clematis integrifolia

Sanguisorba minor

Viola elatior

Festuca rubra

Equisetum arvense

Lysimachia vulgaris

Trifolium sp

Knautia arvensis

Filipendula ulmaria

Vincetoxicum hirundinaria
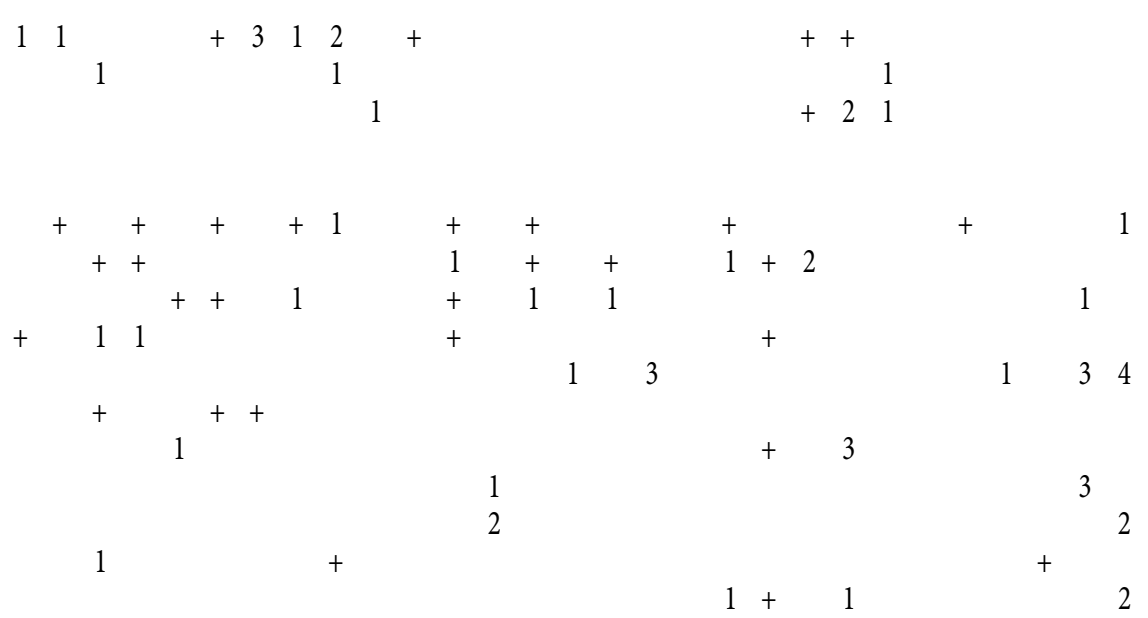

Total species no.

$161815151718222124151718171522232123 \quad 201711 \quad 13 \quad 7 \quad 811 \quad 9181916$

\author{
Average height of vegetation $(\mathrm{cm})$ \\ $\%$ mosses \\ $\%$ bare ground \\ $\%$ litter
}

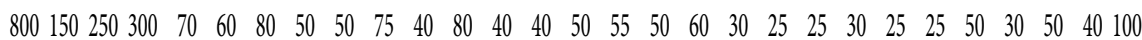 $\begin{array}{lllllllllllllllllllllllllllll}0 & 0 & 0 & 0 & 1 & 1 & 65 & 50 & 20 & 13 & 5 & 0 & 5 & 0 & 0 & 0 & 0 & 0 & 1 & 5 & 90 & 2 & 90 & 0 & 0 & 60 & 75 & 0 & 0\end{array}$ $\begin{array}{llllllllllllllllllllllllllllll}0 & 0 & 40 & 50 & 0 & 0 & 0 & 0 & 0 & 0 & 0 & 1 & 2 & 0 & 0 & 0 & 1 & 0 & 7 & 5 & 2 & 0 & 5 & 0 & 0 & 20 & 10 & 20 & 0\end{array}$

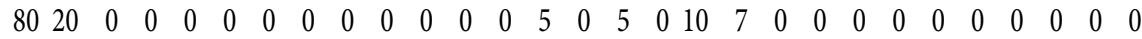

Table 1: Relevés from Slovenian sites. Species in 2 relevés or less are listed separately. Site codes as follows 1: Palško Jezero; 2: Petelinjsko Jezero; 3: Kalsko Jezero; 4: Veliko Zagorsko Jezero; 5: Veliko Drskovško Jezero

Species in two relevés or less: relevé 1: Carex cf nigra 1; relevé 3: Cicuta type +; relevé 4: Cicuta type +; relevé 5: Angelica sylvestris +, Taraxacum vulgare agg. +; relevé 6: Festuca sp. +, Plantago lanceolata +; relevé 7: Rhamnus cathartica seedling +; relevé 9: Plantago lanceolata 1, Pseudocalliergon lycopodioides 1, Hypericum sp. +, Rumex crispus +, Hygrohypnum luridum +; relevé 10: Amblystegium humile +; relevé 12: Thalictrum sp. +; relevé 13: Potentilla erecta 2, Asphodelus sp 1,. Danthonia decumbens 1, Trifolium sp. 1, Hypochoeris $s p+$ +; relevé 14: Serratula tinctoria +; relevé 15: Carex sp +, Leucanthemum vulgare +; relevé 16: Avenula sp. 1, Leontodon type +, Rhinanthus minor +, Sedum sp. +, Trifolium pratense +; relevé 17: Avenula sp. 2, Asphodelus sp. +, Carex sp. +, Fragaria +, Leontodon type +, Sisyrhinchium sp. +, relevé 18: Betonica officinalis +, Melampyrum sp. +, Serratula tinctoria +; relevé 19: Lotus sp. 1, Lysimachia sp +, Viola sp. + Leptodictyum riparium +; relevé 20: Galium boreale 3, Carex sp. 1, Lychnis flos-cuculi +, relevé 21: Lotus sp. 2, Leptodictyum riparium 1, Pseudocalliergon lycopodioides 1, Scorpidium revolvens 1, Hygrohypnum luridum +; relevé 22: Lotus sp. 2, Amblystegium humile 1; relevé 23: Lysimachia sp. 3, Thalictrum sp.1; relevé 25: Rumex crispus 1; relevé 27: Cardamine sp. 1, Leucanthemum vulgare +, Rosa sp. +; relevé 28: Trifolium sp. 3, Trifolium repens 1, Cichorium intybus +; relevé 29: Galium mollugo 3, Veronica chamaedrys 2, Festuca cf arundinacea 1, Pimpinella cf major 1, Nardus stricta +, Rhinanthus minor +, Taraxacum vulgare agg. +. 


\section{DISCUSSION}

\section{Comparison of vegetation sampled with Irish turlough vegetation}

The most salient point is that vegetation representing moist calcareous grassland in Slovenia, is more typical of $d r y$ unfertilised calcareous soils in Ireland. The moisture gradient evident, especially within Petelinjsko jezero, suggests that the Slovenian sites are at the top end of a continuum grading into communities indicative of permanent moisture in Ireland.

The presence of species such as G. verum, Lotus corniculatus and Agrostis stolonifera shows a similarity with the limestone grassland of usually dry areas around turloughs that are not intensively farmed, characterised by Festuca rubra, Agrostis stolonifera and Trifolium repens, as well as Carex panicea, C. flacca, Achillea millefolium, Lotus corniculatus and Centaurea nigra (MacGowran 1985; Goodwillie 1992; Goodwillie 2003). It resembles the Centaureo-Cynosuretum galietosum sub-association in the Molinio-Arrhenatheretea, which is common in unimproved calcareous grasslands in Ireland (O'Sullivan, 1982). Most of these species occur in the Slovenian sites (though Centaurea jacea replaces C. nigra), but occur throughout the basin and must therefore be subjected to more flooding than in Ireland.

The Irish turloughs support more moisture-tolerant species and the main plant communities described from turloughs fall within the Caricion canescenti-nigrae (of the class Scheuzerio-Caricitea fuscae) and the Agropyo-Rumicion crispi (in the Plantaginetea majoris) (O'Connell et al. 1984), the latter indicating a slightly enriched substrate. Sedges are common in the Caricion canescenti-nigrae but in the Slovenian sites described they are infrequent, except for Carex humilis.

The presence of Molinia caerulea, in Slovenia as well as in Ireland, is indicative of more peaty and slightly acid soils. However turlough peat grassland, with a dominance of M. caerulea, is not common and is often associated with shallow, oligotrophic peats (Goodwillie, 1992; Goodwillie et al., 1997). Filipendula vulgaris, frequent in the Slovenian relevés, is rare in Ireland and, in turloughs, is associated more with species of drier limestone grassland vegetation, only flooded in exceptionally wet winters.

The plant community found only in the wettest zone of Petelinjsko jezero is the most similar to the flora found in Irish turloughs. Although two of the dominant species, $A$. angulosum and $P$. altissima are absent from Ireland, the presence of several other wetland indicators including Oenanthe cf lachenalii and Agrostis stolonifera render it most similar to an Irish turlough plant commu- nity. Both Galium palustre and $R$. repens are very widespread in turlough vegetation and $P$. reptans defines a variant of the Ranunculo-Potentilletum anserinae association within the Agropyro-Rumicion crispi (O'Connell et al. 1984). The particular dissected leaf form of $R$. repens noted in Petelinjsko jezero has been described as peculiar to many Irish turloughs (Lynn \& Waldren 2003).

\section{Other comparisons in relation to the vegetation}

One striking difference between the Pivka sites and turloughs, is the presence of trees and shrubs in the basins of the former. In turloughs, the duration of flooding appears to prevent tree and shrub growth in the central basin (Goodwillie 2003), creating a clear lower limit for trees at one height around the basin and within this, there is a shrub zone. Only one of the Pivka sites visited, Petelinjsko Jezero, which is flooded for the longest, was completely free of trees or shrubs within its basin. Some of the other sites also had an apparent tree-line and shrub zone around the basin, but many also had certain shrubs and/or trees growing within the basin. In Palško jezero, there were extensive stands of Salix purpurea, and many sites also supported species such as Rhamnus cathartica and Frangula alnus. Mechanisation is said to have contributed to this in recent years, leaving uneven areas uncut, resulting in the spread of willows (Erjavec \& Peršič 2005).

Mosses were abundant in parts of Palško, Petelinjsko and Kalsko jezeros, mostly in the mid-region of the basin. Turloughs may also support extensive moss cover, especially in the less flooded and more grazed sections (Moran et al. 2008a \& b). The moss Cinclidotus fontinaloides, normally associated with wet margins of lakes and ponds, can cover rocks and boundary walls in turloughs, but was not noted at the Pivka sites. Algal paper is the dried whitish remains of green filamentous algae left after the floods recede from the deeper parts of a basin. This is particularly common in Irish turloughs (Scannell 1972) and was also found within the Pivka site estavelles.

The flora of the large poljes visited outside the Pivka valley also had vegetation similar to that of temporary wetlands in Ireland. Potentilla anserina, a very common species of turloughs, was noted at the edge of Cerkniško polje, though not in the Pivka valley. However the communities of these large poljes may also be more mesotrophic than the Pivka sites (see Gaberščik et al. 2003) and are reminiscent not of turloughs, but of the riparian flood meadows, or callows, of Ireland (Heery 1991) and Europe (e.g. Grévillot \& Muller 1996). These flood 
in winter when the river rises substantially, but are dry in summer and many are cut in late summer for hay.

\section{Climatic differences and their effects on temporary lake vegetation in the two regions}

The key feature that both the west of Ireland and the area around Postojna have in common is the relatively high and constant average monthly rainfall (Fig 3). This results in the accumulation of groundwater, which reaches the surface in winter months when evapotran-

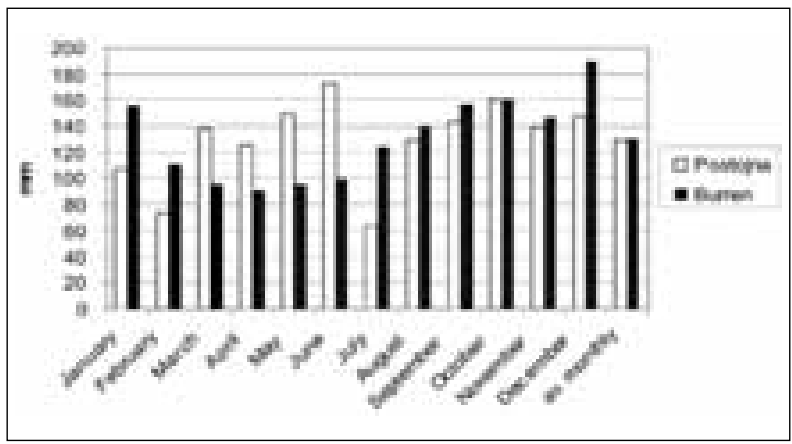

Fig. 3: Average monthly precipitation 1980-90 in Postojna and the Burren (Statistical Office of the Republic of Slovenia (web site listed in references) and Drew 1990).

spiration is much lower (Drew 1990). However, Slovenia has a more continental climate than Ireland and Postojna is also some ten degrees of latitude further south and ca $500 \mathrm{~m}$ higher, than the Irish turloughs which are mostly near sea-level. Thus Slovenian winters are colder and the temporary lakes freeze for several months, resulting in a much shorter growing season than Ireland - where grass can grow even in winter (Collins \& Cummins 1986). The Slovenian summer has more intense sun and warmer temperatures. The mean of $17.38^{\circ} \mathrm{C}$, (June-Aug 1980-2000) obscures the occasional heat-wave with temperatures reaching $30^{\circ} \mathrm{C}$, which, coupled with an upland permeable karst limestone, will result in a more rapid and complete drying of the flooded basins. The cool (mean $14.05^{\circ} \mathrm{C}$, JuneAug 1980-1999) and relatively wet summers of Ireland make it possible for many species normally associated with moist soils on the continent to occur in shallow exposed soils such as those of karst limestone, while the shallow soils of the Slovenian karst landscape surrounding the basins dry out in summer and support more xeric communities.

As in Ireland, the flooding in Slovenian karst depends on the variable incidence of rainfall, with the most sustained rainfall in the winter months (November is normally the wettest month $-\mathrm{A}$. Kranjc, pers. comm.). Petelinjsko jezero floods for ca 6 months and
Palško jezero for 3 months, but there can be in addition short flooding times of a few days even in the summer months (A. Kranjc, pers. comm.). The other sites are nearer the Pivka River, but the volume and amplitude of water is much smaller (Kovačič \& Habič 2005) and it is likely they do not retain water for as long. The short retention time is linked to the altitude, resulting in rapid evacuation of the backed-up waters in the drier seasons.

The lack of glaciation in the Pivka region has enabled the temporary lakes to develop without being eroded by glaciers or by the deposition of glacial drift. This would account for differences in their shape, compared to Irish turloughs, where flat floors and uniformly steep sides are absent. It could also account for the varying - and apparently lesser - amounts of sediment on the basin floors of turloughs.

\section{Climate differences and agriculture}

The temporary lakes in each country provide a different resource for local farmers. In Ireland, turloughs are important as summer grazing and a winter water source for stock in a limestone landscape that does not retain water (Sheehy Skeffington \& Gormally 2007). In Slovenia, the winters are too cold for stock to graze outside and the hot summers dry out most of the limestone terrain, except in the temporary lakes and river valley floors, where the deeper sediments retain the winter moisture long enough for hay or silage production.

Because both Irish and Slovenian temporary lakes provide important resources for traditional farming in the limestone landscape, both are traditionally shared by the local farmers. In Slovenia they are divided into strips for harvesting the hay and in Ireland the adjacent farmers' fields radiate out around the turlough with the centre of many of the larger ones being shared as commonage (Sheehy Skeffington \& Gormally 2007).

Grazing did occur on the Pivka temporary lakes as they dried out, presumably before the hay was allowed to grow, but not on Petelinjsko jezero, which is flooded well into April and produced only hay, which was cut from the end of July (Erjavec \& Peršič 2005). Many villages shared a herdsman, hired in for the grazing season, but this communal system of grazing died out in the mid1960s (Erjavec \& Peršič 2005). In Ireland, the upper edges of some turloughs have ridges and furrows indicating past use for potato growing, but there is no record of hay being cut.

The cutting of Slovenian sites for hay results in a richer mix of forbs, as in Irish flood-meadows (Heery 1991). The summer grazing of Irish sites selects for grass species and early flowering forbs. This also accounts for 
the differences in the two floras. The low-intensity of both farming systems, has enabled the survival of rare plant and animal species in both.

\section{Differences in geomorphology}

The Pivka sites are solution dolines or bigger depressions and other larger depressions may be remnants of former levelled surfaces (A. Mihevc, pers. comm.) Turlough origins are more complex and include glacial activities (Coxon \& Coxon 1997).

Temporary lakes in karst landscapes are thought to occur where the water table rises due to one of several possible features (Gams 2004). In Slovenia both the large poljes and the Pivka temporary lakes occur in valleys which were created by faulting. The Pivka water table is arrested due to the local presence of flysch rock, thrust against the porous limestones within which the basins occur (Kovačič \& Habič 2005). In the Irish Burren uplands, impervious clays and limestones impede drainage of turlough basins (Drew 1990), but most turloughs are almost at sea level, which controls the local water table.

\section{Summary comparison between Irish turloughs and the temporary lakes of the Pivka valley}

- Both are basins in karst landscapes. The Pivka sites appear to have been caused by collapsed or levelled systems; turlough origins are more complex and they have been glacially scoured.

- Both flood seasonally due to heavy rainfall regimes and are usually mostly dry in summer, but can partially fill in summer if there is high enough rainfall.

- In most turloughs, flooding occurs principally via estavelles and springs. This is the case for at least four of the Pivka sites.

- The size range is similar, though the depth of the flooded Pivka temporary lakes is greater.

- In both, sediment remains on leaves after flooding and a strand-line of dead vegetation occurs around the edge of the basin.

- Algal paper occurs extensively in turloughs, and was also found in some of the Pivka sites, especially at Petelinjsko jezero.

- The only Pivka site which had a plant community resembling that found in turlough basins was Petelinjsko jezero. Some Pivka sites supported other wetland species, including willows and most of them supported species confined to the basins which occur on the margins of Irish turloughs.

- Both the Pivka sites and turloughs provide an important resource for local farmers in a limestone landscape.
Most of this is traditionally shared, in strips (Pivka sites) or wider, but linear fields or as commonage (Ireland). Turloughs are used as summer pasture and a winter water source for stock, while the Slovenian sites are primarily cut as hay.

- The seasonal nature of both has resulted in little modern agricultural improvement so that both are refuges for wildlife that has become scarce elsewhere. Both include legally protected sites, but turloughs are specifically defined in the EU Habitats Directive, while poljes and related temporary lakes are not.

- With the exception of a few turloughs which occur in the Burren uplands, most are low-lying while the Slovenian intermittent lakes are in uplands.

- The Pivka sites have thick layers of sediment forming flat basin floors. Irish turloughs vary with respect to sediment depth and floor flatness.

- Duration and time of flood appears to prevent growth of trees and shrubs in the centre of turloughs. This appears to only be the case in Petelinjsko jezero which is the only Pivka valley temporary lake that regularly floods for up to 6 months, rather than 3 months or less.

- Both support a variety of rare flora and fauna.

\section{Are the Pivka valley temporary lakes turloughs?}

Whether the temporary lakes of the Pivka valley can be considered as turloughs depends on the definition adopted for turloughs. Most definitions of turloughs in the literature do not specify flora or fauna, but may mention that they support species associated with wetlands (Coxon 1987; Working Group on Groundwater 2004). However, the important aspect may not be whether the flora comprises actual wetland species but whether the basin flora (and also possibly the fauna) is absent from both the surrounding drier land and from permanent wetlands. Species are often found in these sites because of the temporary nature of the wetland. In Ireland, much of the basin contains mesic grassland, sedge communities, occasionally true wetland species. In the drier Slovenian landscape, species that occur in the basins are only relatively mesic, excluded from the xeric conditions of the surrounding land.

Most turloughs flood and empty by estavelles and springs and the principal water source is karst ground water. All of them are also actual hollows within the limestone. The way the flooded parts of the large poljes function and the resulting effect on the biology is distinctly different to turloughs. This appears to be due to their origin by faulting and slippage. However, the Pivka valley systems are, like turloughs, hollows within the limestone. Perhaps these hollows have been caused in a 
different way to turloughs (obscured by subsequent glaciation) but the resultant flood regime and ecology are the same.

It would appear to us that the important elements defining turloughs are that:

1. They are temporary water bodies, flooded each year, principally in winter months, usually dry in summer.

2. They occur as discrete hollows entirely within karst limestone and flooded principally by karst ground water.

3. In their natural state, they support a flora and fauna assemblage that is present due to the seasonal flooding.

Petelinjsko jezero seems to be clearly a turlough by any definition; it fills and drains by estavelles, trees and shrubs appear to be excluded by flooding, and in the basin floor it supports similar wetland vegetation to Irish turloughs. The other sites described support only a few true wetland species, such as Agrostis stolonifera or Oenanthe cf lachenalii and scrub, where it occurs in the basin, includes species such as Salix purpurea, Rhamnus cathartica and Frangula alnus. But the flora assemblage present in their basins, although not one associated in Ireland with wetlands, is clearly there due to the seasonal flooding. Thus, using the definition above, these temporary lakes can also be termed 'turloughs'. Klenski dol which we visited but did not record appears not to be flooded every year and as such, would not qualify as a proper turlough. The remainder of the temporary wetlands in the Pivka valley and the few in the adjacent Reka valley have not been visited and therefore cannot yet be described in relation to turloughs.

\section{Descriptive Terms}

Because Slovenia has such extensive and well-known areas of karst landscape, its language has become part of geomorphological definitions. The word karst derives from the SW Slovenian karst region of Kras. Dolina, used to describe karst depressions, is the Slovenian for valley, while polje means 'field' and its technical use to describe only the larger depressions is confusing to ordinary Slovenians. These terms were probably adopted by Austrian scientists describing the landscape, much as in Ireland, where English-speaking authors adopted Irish words such as bog and esker to describe Irish landscape features. Turlough is also an Irish word but used by local people just to describe a temporary lake. It is sometimes said to derive from the Irish for dry lake, but it probably means 'drying-out place' (Sheehy Skeffington et al. 2006). This Irish meaning and the use of the term 'field' by the Slovenians for the temporary lakes, indicates how both peoples were more interested in the grazing or haymaking potential of these areas, as an important aspect of the traditional agricultural landscape, than in their water (lake phase).

It also should be noted that the technical term polje does not describe a large temporary wetland as often assumed in the English literature, but a large enclosed valley system within the limestone landscape. This can be partially temporarily flooded, but does not need to be. In the same way dolina is a small karst depression and uvala a medium-sized one. There appears to be no term for a temporary flooded system as such. This is because these terms have been defined by geomorphologists who are interested in how landscape features are caused rather then the biology they support.

\section{CONCLUSION}

The following definition for a turlough is proposed:

Turloughs are depressions entirely within and on karst limestone, annually inundated mostly by groundwater via estavelles and springs and, in their natural state, supporting vegetation and/or soils indicative of the prevalence of wetland conditions over at least part of the year.

Under this definition, many of the temporary wetlands of the Pivka valley are turloughs. We suggest Slovenian scientists should adopt this term to describe them, at least as an ecological term if not also as a geomorphological term.
The larger temporary wetland sites that occur in the Slovenian karst landscape need their own name which appears to have become polje, even though this actually means a large depression, wet or dry, in geomorphological terms, and a field in Slovenian. We do not have sufficient familiarity with them to propose a definition or venture a new term to describe them. But we do suggest that any systems similar to them found elsewhere, including one in the Burren uplands of Ireland, should also be called polje.

We also propose that both turloughs and poljes be recognised in the European Habitats Directive and that this recognition not confine them to any particular coun- 
try. Both are unique and rare ecosystems with distinctive floral and faunal assemblages but neither appears to be confined to one country. The temporary nature of these wetlands means most have not been seriously altered by agricultural improvement. They have a distinctive traditional management, which is an important part of the cultural landscape and which has contributed to their biodiversity. This is now under severe threat from the changes in land use both in Ireland and Slovenia.
Although most Slovenian poljes already have other protection, such a change to the European Habitats directive would make it much clearer why these sites should be protected and also most importantly, it would give protection to any other such temporary wetlands in karst landscapes that might occur elsewhere in the present European Union or in countries which later join the Union.

\section{ACKNOWLEDGEMENTS}

The authors are grateful to all at the Karst Research Institute in Postojna Slovenia, for the very warm welcome they gave us and for advice and help. In particular we wish to thank both Andrej Mihevc and Andrej Kranjc for very helpful advice and information, Tanja Pipan for inviting MSS and for much useful information and corrections to the MS, Jani Mulec for conference support and site visits and Franci Gabrovšek for the loan of bicycles. We are also indebted to Janez Ferjančič for originally taking NS to see the Pivka sites and for translation help and to Janez' parents, Anka and Josef Ferjančič for their incredible hospitality. We also thank Niall Brooks, Climatology Section, MetÉireann for rainfall data on the Burren, Catherine Coxon for help with definitions and references and Caroline Sullivan for help with the ordination

\section{REFERENCES}

Anon., 2003: Interpretation Manual of European Union Habitats Eur 25. European Commission DG Environment Nature and Biodiversity, Brussels.

Campbell, S., Gunn, J. \& Hardwick, P., 1992: Pant-y-llyn -the first Welsh turlough? Earth Science Conservation 31, 3-7.

Chytrý, M. \& Tichý, L.2003: Diagnostic, constant and dominant species of vegetation classes and alliances of the Czech Republic: a statistical revision. Folia Facultatis Scientiarum Naturalium Universitatis Masarykianae Brunensis, Biologia 108. Masaryk University, Brno, Czech Republic.

Collins, J. F. \& Cummins, T., 1986: Agroclimatic Atlas of Ireland. Agmet, Dublin.

Coxon, C.E., 1986: A Study of the hydrology and geomorphology of turloughs. PhD thesis, Department of Geography, Trinity College Dublin.

Coxon, C. E., 1987: An examination of the characteristics of turloughs using multivariate statistical techniques. Irish Geography, 20, 24-42.
Coxon, C. E. \& Coxon, P., 1997: A pre-Pliocene or Pliocene land surface in County Galway, Ireland. In: Palaeosurfaces: Recognition, Reconstruction and Palaeoenvironmental Interpretation, Widdowson, M. (ed.). Geological Society Special Publication No. 120 , pp. 37-55.

Drew, D., 1990: The hydrology of the Burren, County Clare. Irish Geography, 23, 69-89.

Erjavec, M. \& Peršič, M., 2005: Living with the lake, living without the lake. An introduction into the research of the way of life by the intermittent karstic lakes Petelijnsko Jezero and Palško Jezero. Acta carsologica 34 (3), 784-814.

EEC, 1992: Council Directive 92/43/EEC on the conservation of natural habitats and of wild fauna and flora. Official Journal no. L 206, 27.7.92.

Ford, D. \& Williams, P., 1989: Karst Geomorphology and Hydrology. Chapman and Hall, London.

Gaberščik, A. Urbanc-Berčič, O. Kržič, N. Kosi, G. \& Brancelj A., 2003: The intermittent Lake Cerknica: Various faces of the same ecosystem Lakes \& Reservoirs: Research \& Management 8 (3-4), 159-168. 
Gams, I., Kunaver, J. \& Radinja, D., 1973: Slovenska kraška terminologija [Slovene Karst terminology], (Kraška terminologija jugoslovanskih narodov, knj. 1). Katedra za fizično geografijo Oddelka za geografijo FF, Ljubljana.

Gams, I., 2004: Kras v Sloveniji -v prostoru in času. Založba ZRC, Ljubljana.

Goodwillie, R., 1992: Turloughs over 10ha: Vegetation Survey and Evaluation. Internal report to the $\mathrm{Na}$ tional Parks and Wildlife Service, Office of Public Works, Dublin.

Goodwillie, R., 2003: Vegetation of turloughs In: Wetlands of Ireland. Distribution, ecology, uses and economic value, M.L. Otte (ed.). University College Dublin Press, Dublin, pp. 135-144.

Goodwillie, R., Heery, S. \& Keane, S., 1997: Wetland vegetation on the Gort lowlands. In: An Investigation of the Flooding Problems in the Gort-Ardrahan Area of South Galway, Southern Water Global Ltd (ed.). Ecology Baseline Study Volume 1. The Office of Public Works, Dublin, pp. 1-131.

Grévillot, F. \& Muller, S., 1996: Etude de l'impact des changements des pratiques agricoles sur la biodiversité végétale dans les prairies inondables du Val de Meuse: présentation méthodologique et premiers résultats. Acta botanica Gallica 143 (4/5), pp. 317-338.

Heery, S., 1991: The plant communities of the grazed and mown grasslands of the river Shannon callows. Proceedings of the Royal Irish Academy: 91 (B), 1-19.

Ivimey-Cook, R.B.\& Proctor, M.C.F., 1966: The plant communities of the Burren, Co. Clare. Proceedings of the Royal Irish Academy 64 (B), 211-301.

Knez, M. \& Slabe T., 2005: Lithostratigraphic characteristics of the intermittent Pivka lakes region and Matijeva jama cave estavelle. Acta carsologica 34 (3), 582-598.

Kovačič, G. \& Habič, Š., 2005: Intermittent karst lakes of Pivka basin (SW Slovenia) during high waters in November 2000. Acta carsologica 34 (3), 619-649.

Kranjc, A., 2006: Excursion to karst seasonal lake Cerkniško jezero. Lake of Cerknika. Field Guide for $14^{\text {th }}$ international Karstological School "Classical Karst”, Postojna, Slovenia, 2006, pp.15-18.

Lovka, M., 2000: Flora in vegetacija. In: Inventariizacija Favne, Flore in Vevegetacije Pivške Jezer, Tome, D. (ed.). Nacionalni Institut za Biologijo, Ljubljana, pp. 8-15.

Lynn, D. E. \& Waldren, S., 2003: The turlough form of Ranunculus repens. In: Wetlands of Ireland. Distribution, ecology, uses and economic value, M.L. Otte (ed.). University College Dublin Press, Dublin, pp.157-9.
MacGowran, B., 1985: Phytosociological and ecological studies on turloughs in the west of Ireland. $\mathrm{PhD}$ thesis, Department of Botany, University College, Galway.

Mihevc, A., 2006: Classical karst. Field Guide for $14^{\text {th }}$ international Karstological School "Classical Karst", Postojna, Slovenia, 2006, 19-30.

Moran, J., Kelly, S, Sheehy Skeffington, M and Gormally, M. (2008) The use of GIS techniques to quantify the hydrological regime of a karst wetland (Skealoghan turlough) in Ireland. Applied Vegetation Science 11: 23-34.

Moran, J., Sheehy Skeffington, M and Gormally, M. (2008) The influence of the hydrological regime, soils and management on the plant community composition and species richness of Skealoghan turlough, Ireland. Applied Vegetation Science 11: 1122.

Mucina, L., 1997: Conspectus of classes of European vegetation. Folia Geobotancia Phytotaxonomica 32, 117-172.

Mulec, J., Mihevc, A. \& Pipan, T., 2005. Intermittent lakes in the Pivka basin. Acta carsologica 34 (3), 543-565.

Ní Bhriain, B., Gormally, M. \& Sheehy Skeffington, M., 2003. Changes in land use practices at two turloughs, on the east Burren limestones, Co. Galway, with reference to nature conservation. Biology and Environment. Proceedings of the Royal Irish Academy 103B (3), 169-176.

O'Connell, M., Ryan, J.B. \& MacGowran, B.A., 1984. Wetland communities in Ireland: a phytosociological review. In: European Mires, Moore, P.D. (Ed.), Academic Press, London, pp. 303-364.

O'Sullivan, A.M., 1982: The lowland grasslands of Ireland. Journal of Life Sciences, 3 (1), 131 -142.

Pečnik, M. 2004: NATURA 2000 in Slovenia Shadow List. WWF Austria and Oikos Inc.

Petrič, M. \& Kogovšek, J., 2005: Hydrogeological characteristics of the area of intermittent karst lakes of Pivka. Acta carsologica 34 (3), 599-618.

Pipan, T., 2005: Fauna of the Pivka intermittent lakes. Acta carsologica 34 (3), 650-659.

Ravbar, N. \& Šebela, S. 2004: The karst periodical lakes of upper Pivka, Slovenia. Acta carsologica 33 (1), 159-173.

Scannell, M. J. P., 1972: Algal paper of Oedogonium sp., its occurrence in the Burren Co. Clare. Irish Naturalist's Journal 17, 147-152.

Šebela, S., 2005: Tectonic sights of the Pivka basin. Acta carsologica 34 (3), 566-581. 
Sheehy Skeffington M., Moran J., O Connor Á., Regan E., Coxon, C. E., Scott, N. E. \& Gormally, M., 2006: Turloughs - Ireland's unique wetland habitat. Biological Conservation 133, 265-290.

Sheehy Skeffington, M. J. \& Gormally, M., 2007: Turloughs: a mosaic of biodiversity and management systems unique to Ireland. Acta carsologica 36 (2).

Smith, A. J. E., 2006: The Moss Flora of Britain and Ireland. $2^{\text {nd }}$ ed. Cambridge University Press, Cambridge.

Sweeting, M. M., 1953: The enclosed depression of Carran, Co. Clare. Irish Geography, 2 (5), 218-224.

Sweeting, M. M., 1972: Karst Landforms, Macmillan, London.

Williams, P. W., 1970: Limestone morphology in Ireland. In: Irish Geographical Studies Stephens, N. and Glasscock, R.E. (eds.), Queen's University Belfast, pp. 105-124.
Working Group on Groundwater, 2004: Guidance on the assessment of pressures and impacts on groundwater dependent terrestrial ecosystems, Risk Assessment Sheet GWDTERA2a - Risk to Turloughs from Phosphate. Water Framework Directive Pressures and Impacts Assessment Methodology, Guidance Document no.GW9. Working Group on Groundwater, Sub-committee on Turloughs. Environment Protection Agency, Dublin.

\section{Web site}

http://www.arso.gov.si/podro cja/vreme_in_podnebje/ podnebje/Postojna.pdf Statistical Office of the Republic of Slovenia. Accessed 11.3.07 